\title{
3 Members of the Senate in the Southern Netherlands (Belgium) between restoration and revolution (1815-1831)
}

\author{
Els Witte
}

\section{Introduction}

In the aftermath of the defeats of Napoleon (1814-1815), a number of European states saw the emergence of restoration regimes in which elements of the modern system (citizens with equal rights, freedoms, and political participation; parliaments with legislative and supervisory capacities) coincided with remains of the old regime (a strong monarch with subservient ministers, powerful nobility, an inflexibly repressive government, etc.). Senates referred to the old regime because of the role they ascribed to nobility. In 1814, an interesting version of such a restoration regime appeared in the Netherlands - a country with its own constitution and its own monarch, William I of Orange-Nassau. The founding father of this constitution, G. K. count van Hogendorp, ensured that nobility enjoyed a protected position. There would be knighthoods (Ridderschappen), i.e. electoral bodies consisting of members of the wealthy aristocracy that would exercise a powerful role in the States-Provincial and appoint the members of the StatesGeneral. The constitution of 1814 did not, however, provide for a senate (Eerste Kamer) (Velema 1998; Van Poelgeest 2013).

William I reached an agreement with England to merge the Northern and Southern Netherlands to form a buffer state against France. The other European powers agreed to this United Kingdom of the Netherlands (Verenigd Koninkrijk der Nederlanden). In accordance with the Eight Articles, the Southern Netherlands were granted the right, jointly with the Northern Netherlands, to determine the content of the constitution. In practice, though, the constitution of 1814 was taken as the point of departure. Moreover, in the mixed constitutional commission chaired by Van Hogendorp, it soon became apparent that the South had its own political culture and mental framework and would clearly be making its own demands. One of these was to have a senate (Witte 2016a). Because the Senate was an initiative of the South, which also influenced its composition and functions, I should like to focus here on the Southern members of the Senate. There is also a second reason why these members of the Senate deserve more attention than they have received so far. Unlike their Northern colleagues, for whom little changed until 1848, the Southern members of the Senate, following the change of government brought about in the revolutionary year, 1830, and its aftermath, had to face a major crisis 
that put an abrupt end to their mandates and replaced the restoration Senate of 1815 with a more modern model.

\section{A Senate for the South}

Why the need for a Senate in the South? Of the eleven Southern members of the commission, seven were staunch supporters of the idea. The issue of a bicameral system was therefore bound to feature on the agenda and would give rise to many a heated debate. Five members of the aristocracy - C. count de Mérode, C. count de Thiennes, P. count d'Arschot, C. baron de Méan, and F. du Bois - were strongly in favour of a chamber that would represent the nobility, but even J. Raepsaet, a Flemish traditionalist well versed in old Belgian law, joined the struggle in favour of a Senate (Colenbrander 1908-1909). They were well aware that they represented the interests of the Southern nobility, which, compared with the situation in the North, was twice as large and included many high-ranking aristocrats (princes, marquises, counts, and viscounts). There was the old hereditary aristocracy going back to before the seventeenth century, including a few families that went back as far as the Burgundians. In the seventeenth and the eighteenth centuries, the Spanish and Austrian monarchs had also conferred titles on the basis of exercised functions. Over the centuries, the Habsburg emperors, German monarchs, and especially the French kings had also raised many to the ranks of the aristocracy in the Netherlands. Primogeniture, the system by which the firstborn inherits his parents' estate, was by and large the rule, which meant that land ownership remained concentrated in particular families. However, members of the aristocracy had suffered at the hands of the French republicans and now hoped that their property, rights and privileges would be reinstated and that the ancien régime would be reinstalled (Witte 2015). 'Our nobility must be able to live again' was the wish expressed by De Mérode, and De Thiennes referred to the need to maintain the moral strength of the nobility.

If the nobility were to be represented separately in the Senate, this would restore the prominent role of high-ranking and wealthy aristocratic families in the community. This position was most vigorously defended by Raepsaet. He was in favour of nothing less than a full return to the old constitutions of the period before 1795 and an States-General consisting of three estates. At the very least, he believed that the higher clergy should also be granted the right to sit in the Senate. De Mérode was also in favour of the clergy's being granted legislative power once more. For both these members, as for the other noblemen, the Senate might well have consisted exclusively of members of the hereditary aristocracy. The aristocrats also had their minds set on members elected from among and by the members of the knighthoods and were in favour of a separate voting right based on class distinction. A number of noblemen from the Northern Netherlands sided with their Southern colleagues in the latter's struggle to secure a central position for nobility in the new system (Colenbrander 1908-1909).

During the restoration period, the memory of the French revolution, the French republic, and most certainly the Terror were forcefully driven to the background. 
Republican principles and especially Jacobin ideas were strongly opposed. It was no different in the Netherlands. The restoration elite distanced itself from the Batavian republic of the 1790 s, which would be associated with civil discord, absence of government, and even anarchy from then on. In the South, nobody wanted to be reminded of the period of Robespierre. Even in 1830-1831, i.e. after the revolution, the Constituent Assembly continued to refer to the period with a significant degree of abhorrence. The aristocratic preference expressed by Van Hogendorp in the constitution of 1814 was completely in line with this attitude, which was also obvious in the discussions of the constitutional commission in 1815 (Velema 1998; Witte 2017). Not only aristocrats but also proponents of what would be referred to as aristocratic liberalism made their views known, taking their inspiration from Montesquieu and Benjamin Constant. These ideas were well known: the nobility must be a bulwark against democratic unrest and an antidote to the elected element. In its capacity as a mediating body, the aristocratic Senate could therefore ensure political durability and stability and guarantee a moderate government. This Senate could also mediate between the monarch and the people and prevent both the monarch from becoming despotic and the people from rising up in rebellion (De Dijn 2008).

But what did the king think about all this? Though he did not personally take part in the gatherings of the constitutional commission, he was kept very accurately informed both in writing and orally by Van Hogendorp, and everyone knew that long-time Bonapartist C. van Maanen and former minister J. Mollerus could be relied upon to uphold the interests of the monarch. It was no secret that the king had long cherished ambitions for his now much larger kingdom and that he was prepared to use all the power and authority he needed to achieve them. The king and Van Hogendorp were therefore not in favour of the English model - with its House of Lords and a powerful Parliament. The French Chambre des Pairs was more to their liking, with members chosen for life by the king from among the hereditary aristocracy. However, since there were less members of the hereditary aristocracy in the Northern Netherlands, Northern members of the commission were reluctant to follow suit. Nevertheless, the king was aware of the social importance of Southern noblemen and was keen to establish a link with them - a tie with the monarchy - to associate them with land management and to be able to rely on them. This could, of course, be achieved via the knighthoods and StatesProvincial, but a Senate would be an added advantage. The idea of an aristocratic Senate appointed by the king was certainly not one to be dismissed. Members of the commission who were opposed to a separate estates system might even consider appointment by the king as an acceptable alternative. As De Mérode, D'Arschot, and Du Bois explained, if the members of the Senate could not come from the knighthoods, they could always be appointed by the king (Colenbrander 1908-1909).

Nevertheless, after many discussions, there were still enough members to oppose the idea of an aristocratic Senate - certainly among the Northern members, which included Van Maanen, for instance, who was firmly opposed to any form of privileged estate and to a specific role for the clergy. There were those 
who feared that the pairs (peers) could all too easily impose their own views on the king. There were also a number of liberal members in the South - administrators and magistrates during the French period, such as Dotrenge, De Coninck, and Leclercq, who were equally opposed to privileges for the aristocracy and the clergy. Dotrenge in particular took up the fight against privilege and came into direct conflict with De Mérode and De Thiennes. Former prefect J. B. Holvoet took the middle ground: though he agreed that the aristocracy was politically important, he was not prepared to grant exclusive power to aristocrats and became the rapporteur of a compromise proposal (Colenbrander 1908-1909).

The compromise cut the Gordian knot and received the backing of a majority of the members: there would not be a real aristocratic chamber. The Senate would include members of the moneyed class who could be appointed on the basis of services rendered to the state. There was no mention of the clergy, either. All members of the Senate were to be appointed for life by the king. De Mérode and De Thiennes were now alone in pleading for an aristocratic chamber and were left deeply disappointed. The king's pledge that he would appoint almost exclusively members of the aristocracy in the South did, however, provide some solace. Raepsaet, who was probably disappointed by the turn of events, had longsince returned home. The majority could now agree to the principle of a bicameral system. As the kingdom consisted of two geographical parts, so ran the argument, this could in itself justify expanding the States-General with the creation of a senate (Colenbrander 1908-1909; Witte 2016a). This was mainly a tactical argument, given that the members of the States-General represented the whole nation rather than just one of its constituent parts.

The text that appeared in the constitution considered the wise, moderating role of the Senate. The people's assembly (Tweede Kamer) was (by a matter of degrees) the elected element. The Senate was more associated with the monarchy. Its members were older (at least 40), the location of their assemblies alternated between Brussels and The Hague, and the allowance they received (3,000 fl.) was higher, but they were less numerous (40-60 members compared with 110 in the people's assembly). Members of the Senate would also be able to pass legislation and have the authority to exercise delaying power. By being granted the last say, they would also be able to block proceedings in the people's assembly (De Schepper 1990; Van den Braak 1998).

\section{The Senate: le manège du Roi}

At the time, the Senate was nicknamed Le manège du Roi (the king's merry-goround), in reference to the subservient nature of the members. This denigrating phrase was used especially by the opposition and featured in contemporary sources concerning the Senate. The Southern opposition especially stressed the Senate's docile attitude, and during the Belgian constitutional debates (1830-1831), the image portrayed of the Senate was particularly negative. The Senate was often presented as an example that was not to be followed (National Congress 1830, 13-18 Dec.). This negative image had much to do with the appointment policy of 
William I in general. The king was known for applying a kind of patronage system based on appointing the most loyal members he could find, from whom he would expect little or no public criticism and who would not be allowed to remain in the same position for long. In addition, appointments would also be used on occasion as a form of discipline. Not surprisingly, the king was often criticised for appointing too many 'yes-men'.

The king's appointment policy in the Senate was hardly any different. Nevertheless, membership to the Senate was a much sought-after appointment. Members considered the position to be an honour bestowed upon them by the king, the climax of a career in service of the kingdom, and for the dyed-in-the-wool legitimists among them, proof of the king's trust (Van den Braak 1998; De Schepper 1990). We may ask, however, what happened in practice. Let us focus on the group of Southern members of the Senate appointed between 1815 and 1830-45 appointments, corresponding by and large to the number of Northern members.

Let us first consider whether the king kept his promise and appointed primarily members of the aristocracy (Van den Braak 1998; De Schepper 1990; Almanach 1840; Wapenboek 1990). This was certainly the case. In theory, the king was under no obligation to appoint members on the basis of birthright, though that is exactly what happened in practice. Only two members appointed between 1815 and 1830 are not listed as belonging to the nobility. One of them, P. F. Nicolaï, belonged to an old family of magistrates from Liège and became the ruling president of the supreme court of Liège after his stint as a member of the Senate.

Two former governors, C. de Brouckère and B. J. Holvoet, joined the ranks of the nobility before they became members of the Senate, the former without a title and the latter as a knight. Nevertheless, the vast majority of the Southern members of the Senate belonged to the high and old nobility. This was due to the fact that members were recruited from among the king's court dignitaries (grand marshal, chamberlain, etc.), who were required to have seniority going back several generations, as the dividing line set by the king was the beginning of the seventeenth century (Witte 2015). Some ten members of the Senate belonged to this category, but other members were descendants of equally old families. The princes De Chimay and De Gavre; the marquises De Trazegnies; and the counts De Liederkerke Beaufort, De Bethune, De Berlaymont, De Marnix, and Du Chastel were but a few prominent examples. ${ }^{1}$ All were, of course, more than sufficiently wealthy to sit in the knighthoods of their respective provinces, in which some, such as count Van der Meere de Cruyshoutem, had leading positions. When members were appointed, it was important that no province should feel it was being overlooked, although no formal rules for regional representation existed in the Senate.

How did the king deal with the controversial issue of the presence of the clergy? The king had been unable to reach a compromise concerning the relationship between church and state with Archbishop De Broglie and his intransigent Catholic followers, as a result of which a major conflict had broken out between them. These conservative Catholics were firmly opposed to the religious pluralism provided by the constitution and were not prepared to accept any other religion than Catholicism for the South. The ruling government had to adjust to this 
situation. De Broglie was prosecuted and forced to flee, after which a compromise agreement was made with De Broglie's successor, F. A. prince de Méan. The new archbishop was immediately appointed as a Senate member, which was a clear signal that the king was grateful to the archbishop for his help and was prepared to meet the Roman Catholics halfway (Van Zanten 2004).

Members of the aristocracy in administrative and political positions were also eligible to become members of the Senate. The largest group came from the people's assembly and consisted mainly of non-re-elected members. It included a few members of both the old nobility and the noblesse de robe of the Austrian period, such as counts De Borchgrave, D'Hemricourt, and De Vinck. A minister and a minister of state were also appointed to the Senate: count De Thiennes and baron Goubau d'Hovorst. Liège, the two Flanderses, and South Brabant each had a former governor in the Senate. Count De Carmin moved straight from the States-Provincial to the Senate, and knight De Moreau was a former member of the provincial executive of Namur. Count De Bethune was appointed on the basis of his former position as district commissioner of Hainaut province. Knight Membrede was yet another example of a counsellor of state who became a member of the Senate. Given how members were appointed, it is not surprising that, with time, a number of members of the constitutional commission were also invited to sit in the Senate. This was the case for counts De Thiennes and D'Arschot and knight Holvoet.

The Senate was thus primarily populated with loyal members from the administrative-political sector. But what about the other socioeconomic and socio-political sectors? Only Major General Van der Burch, who was a member of the general staff, was appointed to the Senate from the army. Most nobles were landowners whose large estates could include many villages and for whom farming leases were a major source of income. Therefore, agricultural concerns were also their concerns. Industrial, commercial, and financial activities had not had any bearing on how noble titles were conferred in the past, which meant that no representatives of these sectors could be found among the nobles, except for members of families in the ore extraction business (Janssens 1998; Witte 2015). Baron F. H. d'Anethan, for example, belonged to a family of wealthy steel mill owners in the province of Luxemburg. The cultural and scientific sectors also had a few representatives. Prince De Gavre was a committed freemason and an active member of the Brussels Academy of Arts and Sciences, which had been re-established after its abolition by the French. Viscount De Nieuport played a central part in the institution not only in his capacity as director but also as a distinguished mathematician - one of the few in the South with a truly international reputation in the discipline (Biographie Nationale s.d., De Gavre; Van Bendegem 2018).

In short, the Southern group of the Senate had all the features of a classic restoration-elite dominated by the nobility. Its members all came from families that held different offices in the United Kingdom of the Netherlands. These families were generally fairly extended and had several different branches, and more than one member of more than one generation was typically a public figure. They constituted the social peak of the Southern elite and could therefore not easily be overlooked by the king. 
Were they all the yes-men they were made out to be? The situation needs to be considered with caution, even though little is known about what actually happened in the Senate. The desire to keep the Senate beyond the reach of the people means that sources are very scarce, but it can hardly be denied that the king had managed to appoint a majority of loyal figures. What the king understood by loyalty can be surmised from the circumstances surrounding the appointment of two former governors, De Brouckère and Membrède. Having failed to achieve what was expected from them in their inability to prevent the election of liberals in the States-Provincial, they resigned, were replaced, and were promptly appointed to the Senate, as a kind of punishment. The king always chose the reliable De Thiennes to act as president of the Senate. As a rule, members of the Senate were not in the habit of being critical, since they took their oath to the king very seriously, and respect for the House of Orange grew fast in their midst (De Schepper 1990; Van den Braak 1998; Ramaekers 1989; Witte 2014).

We should also stress the very particular nature of the members of the Senate. Individuals were more important than their mandates. Some of the nobles of the South matched the Orange-Nassaus in terms of pedigree and wealth and they were treated with respect. The members of the Senate generally enjoyed personal relations with the monarch and his family - certainly if they belonged to the royal household or held a position as a minister or governor. Furthermore, the king would air his views in personal after-dinner conversations (Gerretson 1936). Politics were therefore conducted in an atmosphere of 'like-knows-like'. There could, however, also be negative sides to the situation: personal clashes could not be ruled out. Differences of opinion of a political nature were common, but private tensions also occurred. This was the case with G. de Trazegnies, for instance, who was an intimate of the Prince of Orange and was thus tied to the difficult relationship between the king and his eldest son. Della Faille d'Huyse was made to pay because his son was a member of the opposition (De Schepper 1990; Colenbrander 1931; François 1987).

Unfortunately, the records of the deliberations of the Senate do not enable us to follow the workings of the Senate closely. The members of the Senate convened far less frequently than the members of the Chamber of Representatives and gathered for a only couple of days; meetings took place behind closed doors and were regarded as being of little interest to members of the public. Absenteeism was widespread. It was also difficult to trigger discussions. During the meetings, the agenda was observed strictly because many bills and proposals had to be dealt in very little time. The casting of the vote was what mattered. There was little talk of adversarial procedure and even less of an exchange of arguments, the sources confirm. It was only when Membrède became president that the voting occurred after the deliberations (Van Zanten 2004). The Senate had no right of initiative, and its role was restricted to accepting or rejecting proposals. Although the latter did occur, it happened considerably less frequently. Even though the Senate could block bills, the fact is that only six bills were rejected, while 430 were accepted. Comments were made out of principle or for technical reasons, and some fifteen royal bills had to be redrafted, but there were usually few objections (De Schepper 1990). 
Though there was seldom talk of a collective form of opposition in the Senate, we can consider the tax bill of 1821 in this context: the economic interests of the South were under threat, and even in the Senate, the bill was supported by no more than a slim majority, as the Southern members of the Senate - except for a few 'defectors' - all voted against the bill. Matters related to the corn trade were also regarded as sensitive (De Schepper 1990). This, however, does not mean that there were no individual opposition members at work in the Senate. Archbishop De Méan, for example, who had lent his support to the king in the disputed matter of the foundation of the Collegium Philosophicum, changed sides and joined the group of Van Bommel, De Gerlache, and Sterckx, who defended the interests of the church in the name of freedom of education and religion. The attitude of the archbishop naturally influenced other Catholic members of the Senate (Van Zanten 2004). The king's policy with respect to the use of languages was yet another bone of contention. The fact that Dutch was the official language of the central government also generated a great deal of opposition in the South on the part of the French-speaking elite in Wallonia, Brussels, and Flanders. The peers of the members of the Senate voiced this opposition in the States-Provincial, and the members of the Senate expressed their opposition by speaking only French in the meetings and by forcing their Northern colleagues to do the same. Moreover, French was the language they spoke with the king and the king's family. Counts De Renesse and D'Arschot publicly expressed their preference for French, with D'Arschot even referring Dutch as 'ce jargon barbare' (that uncivilised jargon) (Witte 2016b; De Schepper 1990).

From 1828-1829 onwards, it became obvious that a group of liberal and Catholic-liberal opponents in the people's assembly was becoming increasingly more vocal. Southern members set the tone but could rely on a certain amount of support from the North. At the centre of the opposition movement were concerns about freedom of the press, freedom of education, and ministerial accountability. The Catholic liberals focused on religion and freedom of education; the liberals, on freedom of the press and the reinforcement of parliamentarism. There were also heated budget debates in the people's assembly, with opposing votes mainly coming from the Southern members (Van Zanten 2004). Though this all resonated loudly in the people's assembly, there was still strong support for government policy. However, there was also a small group in the Senate, including De Trazegnies, Van der Burch, and De Bethune, that had grievances about freedom of education, freedom of the press, ministerial accountability, and the implementation of the concordat, which they wished to impart to the king. Twelve members, mainly in the South, supported them, but they were unable to win a majority. We have already seen that count D'Arschot was the most fervent opponent - he was the only member of the Senate who voted against the 1830 budget - but count De Spangen was also critical of government policy, which means that the group of members of the Senate who criticised government policy was in fact larger than is generally suggested (De Schepper 1990). It was also a well-known fact that the sons of some of the members of the Senate belonged to the opposition. This was the case with Charles de Brouckère and with the family of baron d'Anethan, for instance. Clément, son 
of the Berlaymont family, joined the pro-Belgian faction, and the son of Van de Meere de Cruyshoutem, who had served in the army in the Dutch East Indies, became one of the leaders of the revolution in 1830 (Witte 2015). This may not have said much about the political position of their fathers, but it certainly did nothing to strengthen the trust that the king had put in them. In short, the mood of opposition had also taken hold of a minority in the Senate, even though, as we shall see, this did not really shake the trust the members of the Senate had put in the House of Orange, except for a few notable exceptions.

\section{An elected senate in an independent Belgium}

Even if opposition leaders in both chambers wanted to introduce a number of changes in the political system, they were not the ones who wanted to take matters further and aim for a separation between North and South. This role was played by the much more radical journalists and other opponents from the educated middle class. They succeeded in diverting the protest of the lower social classes against the social consequences of the economic crisis of 1829-1830 to serve their own political aims. The looting that occurred at the end of the month of August 1830, preparing Brussels for combat to be able to defend the city against the army that would be brought in to restore order, the violent clashes during the September days that caused more than one thousand deaths, the (unilateral) declaration of independence, the change of power by force of arms and the election of a constituent assembly - all of these were very much in line with their strategy (Witte 2010).

The question whether there would be a Senate in the political system of an independent Belgium was high on the agenda of the National Congress. The context in which these debates took place was very different from that of 1815 . A select constitutional committee drafted a preparatory text, but it was the plenary Constituent Assembly, consisting of two hundred elected members of Congress, that made the final decision. The tax quota for voting rights remained as high as ever, but the abolition of the tiered system by the States-Provincial and the introduction of a group of voters with voting rights based on education and position (liberal professions, priests, etc.) provided for a somewhat broader social makeup (Magits 1981; Van den Steene 1963). Those in favour saw the Senate as being in line with monarchical ideas, and since the monarchy had already been accepted by Congress, they could reassure their European neighbours of the virtue of this move, to which the moderate bicameral system also contributed.

There were now fewer conservative aristocrats. The titled nobility represented no more than a quarter of the total number of members. Half of them were strong supporters of the House of Orange, who sat side by side with noblemen who had joined the ranks of the opposition mainly on religious grounds, reacting against the religious policy of the protestant King William I (Magits 1981; Stevens 1981). Both groups, joined by a number of traditionalists and conservative Catholics, defended the interests of the nobility and major landowners. They were in favour of separate, hereditary, and aristocratic representation and therefore also in favour 
of a Senate. A number of members originally supported the idea of appointments by the king from a list of candidates exclusively drawn up by eligible voters from the aristocracy. Others believed that prelates and high-ranking official dignitaries should ex officio be granted a seat in the Senate, a situation that in some ways appeared then to be more conservative than in 1815. The same arguments that had been used then re-emerged: for example, the socio-economic importance of the landowning nobility; its mediating role between the monarch and the people - after all, monarchy had been chosen over the republic; its role as a bulwark against and mitigating influence on the democratically elected Chamber of Representatives; the useful French model of the pairs (peers); and the importance of Southern traditions (National Congress 1830, 13-15 Dec.).

Unsurprisingly, these proposals met with a fair amount of aversion on the part of staunch liberals and even more so of left-wing liberals, democrats, Catholics, and Jacobin-minded republicans. Though the latter group did not command a majority, it was certainly very active and particularly assertive. As far as they were concerned, the ancien régime was now obsolete, and they were totally opposed to an aristocratic chamber. Most of these Jacobins even refused to consider the idea of two chambers, as could be expected. The aristocratic element had to be driven back and the power of the king curbed as much as possible, which meant that a single elected chamber would be sufficient. Furthermore, did a separate chamber for the nobility not constitute an infringement of the principle of equality (National Congress 1830,13-15 Dec.)? In short, the Senate caused a divide in the National Congress of 1830, and a deep chasm appeared between those who held either of the two extreme positions.

The liberals and the Catholics, who had forged a union alliance before 1830 on the basis of freedom-related principles (freedom of religion, freedom of the press, and reinforced parlementarism), wanted to give the new system a chance and were therefore prepared to make concessions and build bridges. A number of liberals showed moderation and quoted, as their predecessors had done in 1815, Montesquieu's preference for the moderating role of the nobility and large landowners, while also drawing on Constant's very similar ideas. Devaux, for example, considered that because they constituted a very influential minority, it was important to give this social group what it wanted. Otherwise, he feared 'that the nobles would continue to challenge our freedoms'. As such, no effort was spared in trying to find a middle road. After many discussions in the commissions and in the central commission, and after long and heated debates in the plenary assembly, a compromise was finally reached, though it was not an easy one (National Congress 1830, 16-18 Dec.).

The principle of equality was left untouched. The idea of a separate chamber for the nobility was abandoned, and appointments by the monarch were suppressed. There would be a senate, but it would be an elected senate, mirrorring the Chamber of Representatives. An initial proposal allowed the Provincial Councils to function as electoral bodies after the model of the Chamber of Representatives in the United Kingdom of the Netherlands and thus to maintain a tiered system. Critics on the left, however, pointed out that the provinces were no longer 
political bodies but administrative institutions. The same limited electoral body with voting rights based on a high tax quota (but not also on education and office) would elect the members of the Senate. The power of the nobles and large landowners would still be protected but now indirectly so. The eligibility tax quota for voting rights was kept high enough $-1,000 \mathrm{fl}$. - so that, in practice, the overwhelming majority would remain in the hands of the wealthy landowners and, accordingly, of the nobility so that the group's privileges would be maintained. The eligibility tax was re-adjusted at the last moment. The patent tax was included on the strength of a very narrow majority so that wealthy members of the industrial, commercial, and financial bourgeoisie could be granted seats in the elected Senate. The theory of equality was thus adapted to the new realities of the sociopolitical power relationships (National Congress 1830, 17-18 Dec.; Witte 2016a; Stengers 1975).

And what part did the members of the former Senate of the United Kingdom of the Netherlands play in all this? With the exception of the staunchly pro-Belgium count D'Arschot, count De Renesse, and marquis De Trazegnies, who had both been elected as members of congress for their loyalty to the House of Orange, none of the members of the Senate took part in the process. They suffered the fate of so many who had belonged to the establishment. Some of them were set upon during the looting and outbreaks of violence. The residence of Prince De Gavre was set alight, and the prince fled to seek refuge in The Hague. The same happened to a member of the Goubau family, and a member of the Du Chastel family was also assaulted. Burgomaster De Bethune was also forced to flee (Witte 2016b). When, in mid-September, the king summoned the members of the States-General to come and discuss the future of the kingdom, members of both chambers left the city for The Hague as the revolutionaries taunted and jeered at their 'députaille'. The administrative separation between North and South under King William I had now become a negotiable subject and a majority of the southern members in both chambers voted in favour. The same happened in the Senate (Smits 1983; Gerlache 1843). In October 1830, the Prince of Orange was in Antwerp, as he tried to save what could still be saved. Count De Borchgrave and baron Goubau were involved in the process, as were members of the Du Chastel and D'Anethan families (Witte 2015).

We have already noted that few members of the Senate were inclined to take up the struggle in the National Congress against the revolution and for the House of Orange. Orangist supporters included members of the Della Faille and De Stockem families. The remaining members of the former Senate reflected the different categories of the Orangist countermovement. Some sought refuge in the isolation of their castles, remaining silent and politically passive. Count De Thiennes, for example, withdrew from public life to the seclusion of his castle in Lombise in the province of Hainaut. Nothing more was heard of C. de Brouckère, C. de Keverberg, and Van der Meere. However, there was also a large group of people who joined the countermovement and openly aired their orangist sympathies. Among them were some twenty ex-members of the Senate. Some of them were even active in the activist core group, including the marquis De Trazegnies, 
baron De Vinck, and count De Borchgrave, but all of them would suffer the fate of the Orangist families and fall into the gaping chasm between Belgium and the Netherlands (Witte 2015).

The former members of the Senate no longer had any ties with the new Senate that was elected at the end of August 1831. Only De Renesse stood firm, while all the other elected members of the Senate were newcomers, mainly conservative Catholics who had also sat in the National Congress. The competition between the nobility and the roturiers (commoners) was much more ferocious than under William I. The elected nature of the Senate and the change of elite had driven the old and high nobility further into the background. The link between aristocracy, landownership, and political power remained strong in the Senate, but aristocratic institutions, such as the knighthoods, the States-Provincial, and the appointed Senate, disappeared and with them also the key role played by the old and high nobility. The latter was replaced by nobles who had not held power or had held only very little power before 1830 and who, as confirmed Catholics, now stood up for the protected position of the church. Accounting for 57 per cent of all members, the nobility still had a majority in the Senate and still topped the social hierarchy, but members of the higher, very wealthy bourgeoisie had now also become a force to be reckoned with (Witte 2015; Stengers 1975).

Another difference with the Senate in the United Kingdom of the Netherlands concerned the assimilation of the powers of the Chamber of Representatives and the Senate. The Senate now had the power to both propose and amend legislation. It convened in public, like the chamber, and its minutes were published verbatim. Nonetheless, it was still the conservative element in the system. The minimum age for membership - the Senate being an institution that was meant to offset the more democratic position of the Chamber of Representatives by its considered and conciliatory attitude - was still 40 . An exception was made for the heir to the throne, who was granted the right to vote at 25 . He had been given a seat in the Senate to help him become familiar with the workings of Parliament. In the Chamber of Representatives, however, the minimum age was 25. The Senate also remained a smaller body, with less than half the number of members with seats in the chamber, but the stabilising element could also be surmised from the fact that members of the Senate could hold their seats for a much longer period before they had to be re-elected. The term was four years for members of the chamber and eight for members of the Senate (Stengers 1999). It soon became obvious that the chamber was much more assertive than the Senate. In the post-revolutionary years, 1831-1832, the atmosphere in the chamber was often tense. The sittings in the Senate, on the other hand, were by and large more serene, and the commotion concerning the banks or acrimonious discussions were by no means the rule, which was probably helped by the status and age of the members. The government could generally rely on much larger majorities in the Senate than in the Chamber of Representatives (François 1999). It appeared, then, that the Senate carefully took into account the task it had been assigned by the Belgian constitutional legislator, as mentioned before. 


\section{A brief final comment}

Let us by way of conclusion briefly put the responsibilities of the Southern members of the Senate of the United Kingdom of the Netherlands into a historical perspective. Their main task during the whole period under scrutiny was to act as the mouthpiece in Parliament of the nation's conservative stratum and counterbalance the somewhat more democratic, elected component of the political system. They represented carefully considered, prudent legislation, which, at the time, was associated with ownership, high social status, and age.

In some respects, this way of thinking was not really new to them; rather, it was actually quite familiar to those who had held offices before 1814 . The South had been part of France for twenty years (1794-1814). Under the Directoire (Directory), it had been the task of the Conseil des Anciens (Council of Elders) to reject or accept the legislative proposals formulated by the Conseil des Cinq Cents (Council of Five Hundred), and though the Senate, which was appointed by Napoleon himself, had been a backup instrument rather than an autonomous body under Napoleon, its members - all over 40 - were required to carefully scrutinise all legislation.

In the United Kingdom of the Netherlands, the Senate was an integral part of Parliament (Staten-Generaal) whose task was to examine the legislation of the Chamber of Representatives and decide whether it could be accepted. It would be difficult to speak of vigorous action on the part of the Senate, but the members did what was expected from them, some much more diligently than others. The government had to be assisted constructively, but the Senate was more than a group of sycophants. For quite a few members of the Senate, being a member was not simply an honorary position. Furthermore, though the Chamber of Representatives thought otherwise, they took their activities fairly seriously.

They had to give shape to the conservative ideas present in society. But could they do this convincingly? There was hardly any societal feedback. Their activities were performed behind closed doors, without the publication of parliamentary proceedings. The natural habitat of most of the group was the high, old nobility people who considered themselves superior to all others classes and led isolated lives far removed from other social groups, with their own values, moral standards, and customs. Had they been elected, they would have had to rely mainly on the support of the knighthoods. Those who had held official positions would also have belonged to the small privileged administrative elite, closely related and subservient to the king's authority.

Inasmuch as that he picked the members of the Senate, the king considered the Senate as one of the places within the political system where he could occupy centre stage without granting too much power to Parliament. The people's assembly was generally far from rebellious, which meant that the Senate was often pleased to lend a helping hand to the king. The king was seldom disappointed, and servility was the most common attitude. In addition to its mandatory tasks, the Senate 
had very few options to actively participate in government. Though designated for life, which provided for a certain degree of independence, the lack of power to propose legislation and check and challenge the actions of the government severely restricted their sphere of influence.

Some members of the Senate were also influenced by early liberal ideas and the desire for political renewal. With the help of the constitutional freedoms, they too wished to exempt church and education from government control. Less power to the government, more checks on the opaque financial policy, and members of Parliament who would have more to say if ministers were made accountable to them - these ideas gradually started to seep through. These were political demands that the king would not take into account - demands that gave rise to a power crisis and also caused the split between North and South in 1830. The change of elites that followed signalled the end of the mandates of almost all Southern members of the Senate.

Their successors operated in a more modern model. The Senate had been the target of considerable criticism in 1830, and the change was now obvious. The basic principle, however, remained the same. Conservative forces had to have their say in the face of advancing liberalism that was clearly growing in bourgeois and middle class circles, but the link with conservative society was now stronger. The nobility no longer monopolised the makeup of the political body - there was now room for the upper stratum of bourgeois society. Members of the Senate now received their mandates from the voters and had to submit to re-elections. The public nature of the proceedings ensured that the voters were kept informed of the actions of the Senate. The primacy of the Chamber of Representatives was reduced. Legislation could now also be proposed by the Senate, and the principle of ministerial accountability also applied to this chamber. Even though Leopold I tried to use his connections with members of the Chamber of Representatives and Senate to exercise more influence than was allowed by the constitution; personal relationships were still important; and members of the Senate remained more docile than members of the chamber of representatives, the Senate was no longer an instrument that the king and the government could use as they pleased.

Members of the Senate were able to carry out their functions without having to face inextricable political crises until the end of the nineteenth century. The Senate was apparently well adapted to the conservative section of bourgeois democracy. When the latter expanded under pressure from democratic forces, the composition of the Senate changed. In line with opinions regarding the exclusion of women from the political system, however, the Senate continued to be the male stronghold it had been throughout the nineteenth century. Not until after the Second World War would the first women take their seats in Senate. It was no different for Dutch-speaking senators. All through the nineteenth century and still at the beginning of the twentieth century, only French was spoken in the Senate, and this would only change under pressure from the Flemish movement. 


\section{Note}

1 Members oth the old aristocracy of the 16th century and before: C.A.A. prince de Gavre, P.J.M.G. marquise de Trazegnies, J.F.A. viscount de Preud'homme d'Hailly de Nieuport, G.G.M. count de Marnix, M.F.H. count de Liedekerke Beaufort, T.H. count de Berlaimont, P. count de Lens de Lichtervelde, P.J.M. count d'Arschot Schoonhoven, C.A.L. count van der Burch, H. count du Chastel. From the Spanish period: M.L.count van der Noot marquise d'Assche, C.count de Renesse Breidbach, C.C. viscount de Vaernewijkck d'Angest, M.F. baron Goubau d'Hovorst, C.F. baron de Stockhem de Heer, M.A.B. count de Bethune d'Hesdigneul, F.L.N. count de Spanghen, C.I.P. count de Thiennes de Lombise, C.C.M. count de Thiennes de Leinbourg et de Rumbeke, J.B. count d'Hane de Steenhuyse, F.H.J. baron d'Anethan, J. della Faille de Leverghem. From the Austrian period: J.G. count de Borchgrave d'Altena, C.A.E. count van der Meere de Cruyshoutem, A.E. count d'Hemricourt de Jemeppes, G.A. baron de Feltz, J.J. baron de Vinck de Wuest Wesel, J.M.G. knight de Moreau de Bioul. F.J. de Riquet prince de Chimay and count de Caraman, F.A. prince de Méan, L.F.G. marquise de Harchies de Vlaemertinghe, I.C. count de Carnin de Staden all had French aristocratic origins. King William I gave C.R. de Néverlée de la Fortelle and C.J.F. de Keverberg d'Aldengoor the title of baron in 1816 .

\section{References}

Almanach de la Cour de Bruxelles de 1725 à 1840 (1840), (Brussels).

Biographie de Nationale (s.d.), Vol. 7 (Brussels).

Colenbrander, H. (1908-1909), Ontstaan der Grondwet (1814-1815). Bronnenverzameling, Vol. 2 (The Hague: Martinus Nijhoff).

Colenbrander, H. (1931), Willem I. Koning der Nederlanden (Amsterdam: Meulenhoff).

De Dijn, A. (2008), French Political Thought from Montesquieu to Tocqueville. Liberty in a Levelled Society? (Cambridge: Cambridge University Press).

De Gerlache, E.C. (1843), Histoire du royaume des Pays Bas, Vol. 3 (Brussels).

De Schepper, H. (1990), 'De Eerste Kamer in het Verenigd Koninkrijk der Nederlanden', in: Postma, A. et al. (eds.). Aan deze zijde van het Binnenhof. Gedenkboek ter gelegenheid van het 175-jarig bestaan van de Eerste Kamer der Staten Generaal (The Hague: Sdu Uitgevers), pp. 15-58.

François, L. (1987), Elite en gezag. Analyse van de Belgische elite in haar relatie tot de politieke regimewisselingen, 1785-1835 (Gent, Unpublished thesis).

François, L. et al. (1999), 'De Senaat, 1831-1893', in: Laureys, V. et al. (eds.), De geschiedenis van de Belgische Senaat, 1831-1995 (Tielt: Lannoo), pp. 44-87.

Gerretson, C. (1936), 'Gesprekken met den koning, 1826-1836', Bijdragen en Mededelingen Historisch Genootschap 57, pp. 110-226.

Janssens, P. (1998), L'Evolution de la noblesse depuis la fin du Moyen Age (Brussels: Crédit Communal).

Magits, M. (1981), 'De socio-politieke samenstelling van de Volksraad', Revue belge d'histoire contemporaine 12, pp. 581-608.

National Congress (1830), 'Meetings'. Available at: www.unionisme.be (accessed 11 March 2019).

Ramaekers, E.P.M. (1989), 'Charles de Brouckère (1757-1850), gouverneur van Limburg, 1815-1828', in: Wieland, J.H.M. et al. (eds.), De gouverneurs van beide Limburgen 1815-1989 (Maastricht: LGOG), pp. 4-25.

Smits, A. (1983), 1830. Scheuring in de Nederlanden, Vol. 1 (Courtrai-Heule: UGA). 
Stengers, J. et al. (1975), Index des Eligibles au Sénat (1831-1893) (Brussels: KVAB).

Stengers, J. (1999), 'De Grondwet van 1831: theorie en praktijk', in: Laureys, V. et al. (eds.), De geschiedenis van de Belgische Senaat, 1831-1995 (Tielt: Lannoo), pp. 31-42.

Stevens, F. (1981), 'Een belangrijke fase in de wordingsgeschiedenis van de Belgische grondwet: de optie voor een tweekamerstelsel', Revue belge d'histoire contemporaine XII, pp. 641-661.

Van Bendegem, J.P. (2018), 'Wiskunde en wetenschap in turbulente tijden', in: Tollebeek, J., Witte, E. and Kurgan, G. (eds.), De wereld van de zuidelijke geleerden. De Académie Royale des Sciences et Belles-Lettres de Bruxelles onder Willem I (Louvain: Peeters Publishers), pp. 119-147.

Van den Braak, B. (1998), De Eerste Kamer. Geschiedenis, samenstelling en betekenis, 1815-1995 (The Hague: Sdu Uitgevers).

Van den Steene, W. (1963), De Belgische grondwetscommissie (1830-1831). Tekst van haar notulen en ontstaan van de Belgische grondwet (Brussels: KVAB).

Van Poelgeest, B. (2013), 'Tussen oud en nieuw: het ontwerpen van de grondwet als een rechtshistorisch mozaïek', in: De Haan, I., Den Hoed, P. and Te Velde, H. (eds.), Een Nieuwe Staat. Het begin van het Koninkrijk der Nederlanden (Amsterdam: Bert Bakker), pp. 67-75.

Van Zanten, J. (2004), Schielijk, winzucht, zwaarhoofd en bedaard. Politieke discussie en oppositievorming, 1813-1840 (Amsterdam: Wereldbibliotheek).

Velema, W. (1998), 'Revolutie, Republiek en Constitutie. De ideologische context van de eerste Nederlandse Grondwet', in: Van Sas, N. and Te Velde, H. (ed.), De Eeuw van de Grondwet. Grondwet en Politiek in Nederland, 1798-1917 (Deventer: Kluwer), pp. 20-45.

Wapenboek van de Belgische adel (1990), Vol. 4 (Brussels).

Witte, E. (2010), La construction de la Belgique, 1828-1847 (Brussels: Le Cri).

Witte, E. (2014), 'De Oranjecultus in België', in: Te Velde, H. and Haks, D. (eds.), Oranje onder. Populair orangisme van Willem van Oranje tot nu (Amsterdam: Prometheus-Bert Bakker), pp. 157-176.

Witte, E. (2015), 'L'aristocratie belge et l'orangisme (1815-1850)', Revue belge de philologie et d'histoire 93, pp. 439-486.

Witte, E. (2016a), 'De Grondwet van het Verenigd Koninkrijk der Nederlanden (1815) en het ontstaan van de Belgische constitutie (1831)', in: Alen, A. et al. (eds.), De Grondwet van het Verenigd Koninkrijk der Nederlanden van 1815. Staatkundige en historische beschouwingen uit België en Nederland (The Hague: Boom-die Keure), pp. 15-44.

Witte, E. (2016b), Le royaume perdu. Les orangistes belges contre la révolution (18281850) (Brussels: Samsa).

Witte, E. (2017), 'Repubic and public sovereignty. The Belgian Case, 1830-1831' (Paper Interdisciplinary Colloquium, 21 Sept. 2017, K.U. Leuven, The Belgian Constitution of 1831).

Witte E. (2018), 'Republic and public sovereignty. The Belgian Case (1830-1831)', Giornale di Storia constituzionale, 35(1), pp. 89-112 


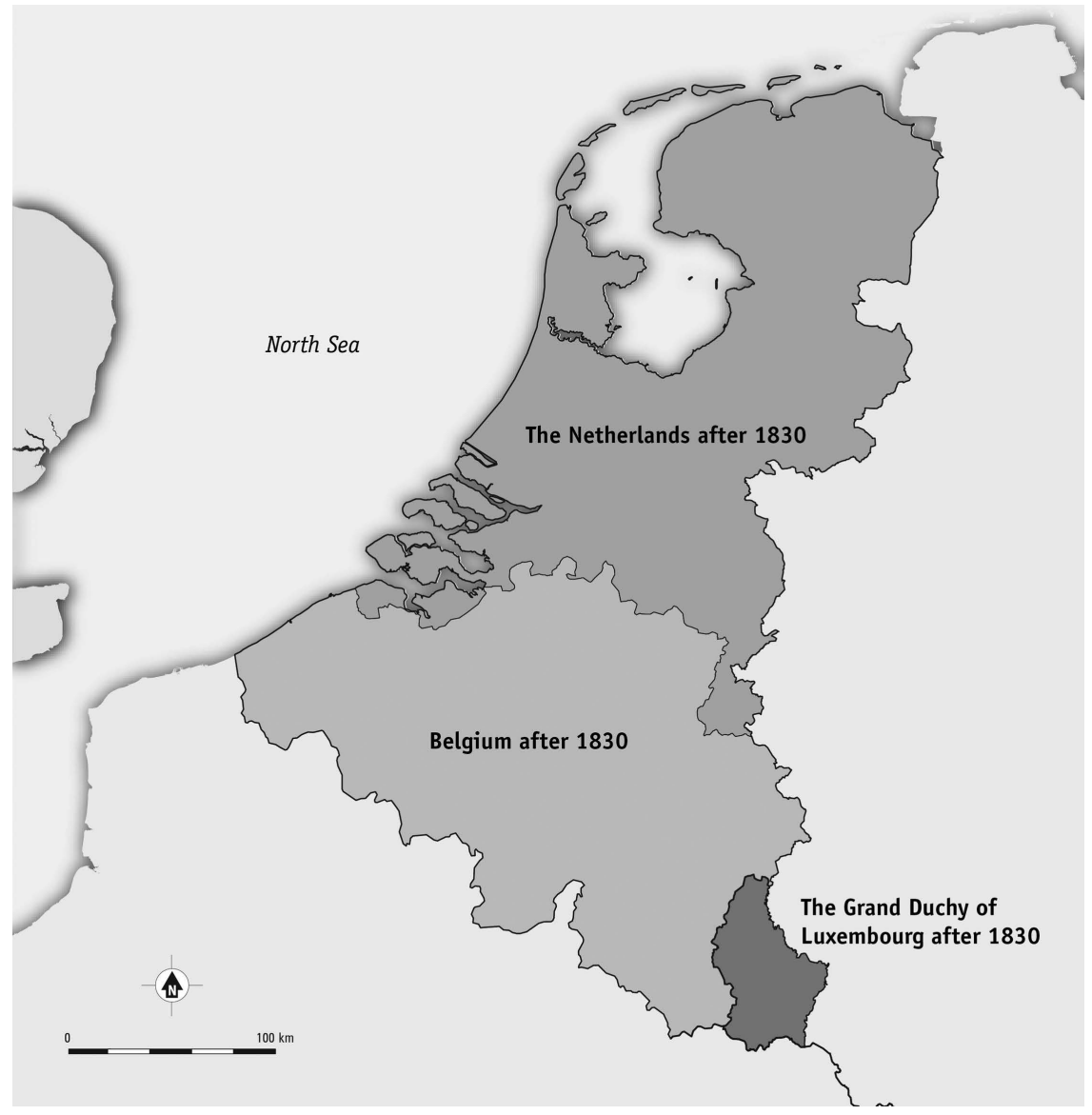

(Bert Brouwenstijn, Vrije Universiteit Amsterdam) 